622.61

\title{
栅原鉱山坑内運搬の能率上昇についで
}

\begin{tabular}{|c|c|c|}
\hline 正会員 & 井 & 上 \\
\hline 正会員 & 石 & 田 \\
\hline
\end{tabular}

\section{On Betterment of Transportation Efficiency at Underground in Yanahara Mine}

Cyuji INOUE and Takeo ISHIDA

\begin{abstract}
Underground transportation is one of the most important factors for the operation of a mine which can be divided into two problems-transportation at working faces and main adits transportation.

High efficiency of transportation at working faces, the author concludes, can only be attained either by adopting a well suited method to the transports employed or its opposite.

Described below are the non-pillar overhand inclined long wall slicing method as an example for the former which uses scrapers as its main transports, and the short wall top slicing with Kappe method (accompanied with filling) as one for the latter which uses baby-conveyors as its main transports.

As regards main adits transportation, however, the descriptions are made with examples based upon the comparisons of:
\end{abstract}

(1) ordinary mine cars and dump cars.

(2) cages and skips, and

(3) belt conveyors and trolley cars.

\section{1. 序言}

柵原鉣山は，下表儿示すように，昭和23年には，月産 $26,241 \mathrm{t}$ を2,500名の人員で寒施していたが，昭和 31 年 上期は月缝 $55,098 \mathrm{t}$ を2,733名の人員でなし遂げた。

\begin{tabular}{|c|c|c|c|c|c|}
\hline 別 & 出鉱量 & 人 & 員 & 1 人当能率 & 備 \\
\hline 昭和23年 & $\begin{array}{r}\mathbf{t} \\
26,241\end{array}$ & & $\begin{array}{r}\text { 名 } \\
2,500\end{array}$ & $\begin{array}{l}\mathrm{t} / \lambda \\
10.5\end{array}$ & 年平均 \\
\hline 昭和31年 & 55,098 & & 2,733 & 20.2 & 上期平均 \\
\hline
\end{tabular}

すなわち 8 年間後に $9 \%$ の人員増で $110 \%$ の生産增を 行つたわけで，これは 1 人当能率で約 $92 \%$ 増加したこと になる。このことは主とし，第1 段階として，昭和26年 完成の 4 万 $t$ 起業で, 主要運搬系統の合理化をなし,(こ れについては，九州鉣山学会誌1）並びに日本鈗業会誌2 に発表）引続き最近梱原本鉱体下部媇しく膨大なる新 鉱体が発見され，採鉝法气の他の改善が行われ増産の一 途をたぞりつつあるので，多少先の報告と重複する点も

\footnotetext{
* 昭和 31 年11月 20 日受理 昭和 31 年秋季大会に扎いて講演

** 同和鉱業株式会社柶原鉱業所所長

*** ” 17 探鉱第二課無
}

あるが，今日 $55,000 \mathrm{t}$ の生産を挙げる末で主として坑内 の運般能率上昇に関して行つて来た事項について簡単に 述へることにする。

一般に坑内運搬を大別すると，主要運搬坑道炕和ける 運搬之, 坑内採鉣切羽火特ける運搬とに別けられる。

主要運搬坑道の運般は，鉱床の賦存状態から考えて出 鉣する量, 運搬する距離及び深さ等を考慮し，その運搬 通路の取り方, 運搬機械または設備の選び方等の決定が 運搬能率に大きく影響するが，採鉣切羽に彩ける運搬 は，鉣石の性質；上下盤岩石の性質等を考えると末た益 々複雑であるので, 我々はこの問題を重要視している。 従来ややるすると，採釷切羽化和ける運般の上昇といえ ば，単に強力な機峨を使用守れば事足りるというょうに 考え勝ちであるが，これだけで性仲々能率上满足出来る 結果が得られず，注とんど総ての場合が採鉣法と合致し た機械を用いるか，または逆にその機械に合致した採鉱 法を適用することにより，初めてその効果を挙げている 場合が多い事を強調したい。

柵原の場合，柵原本鉣体，新鉣体及び周辺鉣体等特の 特のその賦存状況が異なつていて，柵原本体は旧鉣体延 長約 $1,000 \mathrm{~m}$, 幅最大 $450 \mathrm{~m}$, 厚さ最大 $100 \mathrm{~m}$ あり, 新 


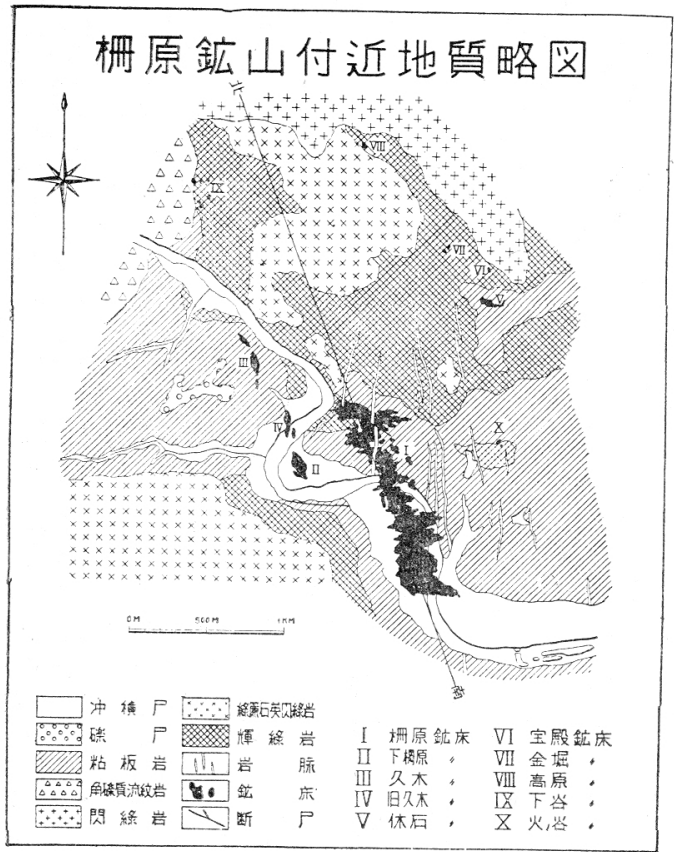

第1図 A

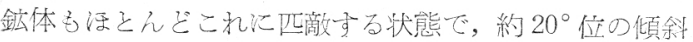
でさらに地下深く延びているが，その他の鉣体はこれと

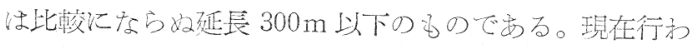
れている採鉸法怯

(i) 残杜式志埧水平上面階段掘法

従来小ら行初ている方法で, 現在子主にこ の方法による

(ii) 分雷傾斜無鉣杜採鉱法

(iii）短壁払式カッい゚採鏔法

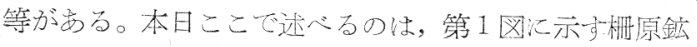

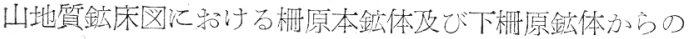
出鉣を主とする主要運搬友び勿羽運般の変薑を説明しよ

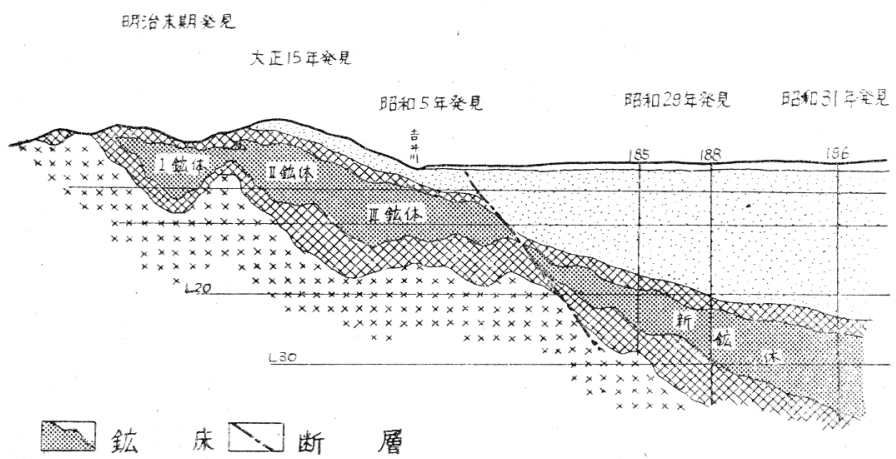

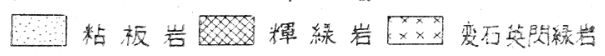
$50 \mathrm{CH}$

第1 図 B 棚原鉱山鉱床断面図
うとするものである。

\section{2. 坑內探鉱切犸の運搬}

からては, 手盛迟に依存していた切羽運搬は逐次機㳦 化が淩透して来石につれて，ローダー，スクレーパーが 便用されて来た。乙か乙採鉣切羽に和ける機械化は，柵

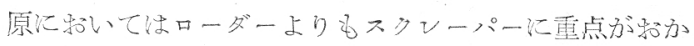
れ, ロ一ダ一は坑道掘進灻主とし, 一部地並の盛达に使 用されている。香た最近はカカッペ切羽の新設ととる

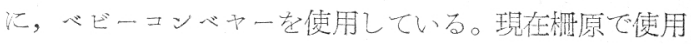
されている切羽運搬機械類の仕様は第1表のようであ り，李たそれ等機栈を使用した場侖の1工当の原紧位成 績は第2 表の如くである。これより手盛, ロ一ダーの1 工当りの能率は余り変化していないが，スリレーパーは 年ととも能率の上暑为目立つている。

序言に女述にたように, 切羽運搬の能率上昇には機㭜 飞合致した採鉣法及び採鉣法に合致した穖械が必要なの で，梱原て㐨ける一例として，前者の場合分層傾斜無鉣

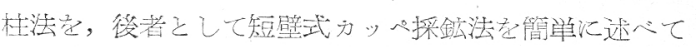
見る。

\section{$2 \cdot 1$ 分㕌傾斜無鉱柱法}

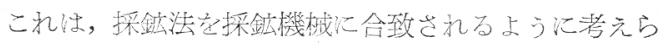

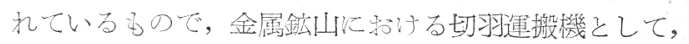
もつ之可優秀之思われるスンレーパーを如何代能率的に 使用するか之いら点化死配慮导れている。この計画の詳 細性省略する分，第 2 四のよう飞 $45^{\circ}$ の昇向の切羽長 $25 \mathrm{~m}$ の長壁切羽茹なしている。

i 段取りの簡素化：一ースクレーパ一作業化和い て，主としてシーブの位置変画等の段取りに要する時間 は案外多く, これは方形の切羽程多くなるので, 搔く 距離の長い短形の切羽，寸なわち長壁式の切羽苾選几で いることと，スクレーパー作業琊魔になる鉣杜を取り 除いている。

ii スラッシャーの大型化 : 一一 クンーパ一採用の当初には，先の移動 に1 回30工程度を要したので,一时ス ラッシャーの小型化を考慮したが，当 鉣山のように比重の重い䤻石には，自 重の山るバケットが必要であり, から 切羽延長を長くすると，バケットの動 く速さが聞題炕なつて来るので, 大型 のスラッシャー㛹用されて来た。現 在使用しているのは, ロープスピード $100 \mathrm{~m} / \mathrm{min}$ の $30 \mathrm{PP}$ スラッシャ一及び $550 \mathrm{~kg}$ のバケットで $100 \mathrm{~m} / \mathrm{min}$ は，

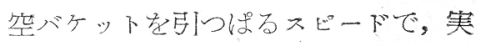
バケットは前にシーブを取りつけ，バ 
第 1 表 切羽運搬機械類仕様表

(a) スラッシャー

\begin{tabular}{|c|c|c|c|c|c|c|c|}
\hline 型 式 & 製 & 作 & 所 & 馬力 & ロープスピード & ロープ径 & 重 量 \\
\hline $\begin{array}{c}\text { ドラム } \\
2\end{array}$ & 日 & & 立 & $\begin{array}{l}\mathrm{P} \\
20\end{array}$ & $\mathrm{~m} / \min _{40}$ & $\mathrm{~mm}_{14}$ & $\stackrel{t}{t}$ \\
\hline 3 & & I" & & 20 & 51 & 14 & 1.1 \\
\hline 2 & 島 & & 津 & 30 & 100 & 16 & 1.5 \\
\hline 3 & & ガー & & 20 & 60 & $14 \sim 16$ & 1.2 \\
\hline 2 & & " & & 10 & 60 & $12 \sim 14$ & 0.4 \\
\hline 2 & 日 & & 立 & 10 & 48 & $10 \sim 12$ & 0.5 \\
\hline
\end{tabular}

(b) スクレーパーバケット

\begin{tabular}{|c|c|c|c|c|c|}
\hline 重 量 & 製 & 作 & 所 & 容 量 & バケット幅 \\
\hline $\begin{array}{l}\mathrm{kg} \\
150\end{array}$ & 自 & 社 & 慗 & $\begin{array}{r}\mathrm{m}^{3} \\
0.15\end{array}$ & $\mathrm{~mm}_{900}$ \\
\hline 180 & & " & & 0.15 & 900 \\
\hline 280 & & " & & 0.25 & 1000 \\
\hline 450 & 東 & 北 機 & 械 & 0.36 & 735 \\
\hline 550 & & ' & & 0.42 & 900 \\
\hline
\end{tabular}

(c) ロ-ダ-

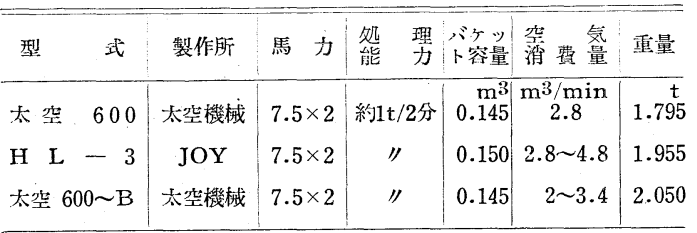

(d) ベビーコンベヤー

\begin{tabular}{|c|c|c|c|c|c|c|}
\hline 型 & スピード & 処理能力 & 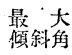 & 馬 力 & ベルト幅 & 重 量 \\
\hline $\mathrm{H}-72$ & $\underset{4.5}{\mathrm{~m} / \min }$ & $\begin{array}{r}\mathrm{t} / \mathrm{h} \\
40\end{array}$ & $18^{\circ}$ & $\begin{array}{r}P \\
1\end{array}$ & $\mathrm{~mm}_{300}$ & $\begin{array}{l}\mathrm{kg} \\
235\end{array}$ \\
\hline $\mathrm{H}-96$ & 4.5 & 40 & $18^{\circ}$ & $\mathrm{kW}_{1}$ & 300 & 295 \\
\hline
\end{tabular}

第 2 表 1 工当原単位成績表

(a)

\begin{tabular}{|c|c|c|c|c|c|c|}
\hline & 単 位 & $29 /$ 上 & $29 /$ 下 & $30 /$ 上 & $30 /$ 下 & $31 /$ 上 \\
\hline 盛(手 盛込 & $t / I$ & 11.32 & 13.83 & 12.86 & 13.28 & 12.38 \\
\hline 笽)機厂ロ一ダ一 & ") & 21.46 & 21.00 & 20.72 & 25.48 & 22.71 \\
\hline 迄（盛〈スクレーパー & " & 26.65 & 30.63 & 25.12 & 41.15 & 46.18 \\
\hline 充 $\int^{\text {栰 }}$ & $\mathrm{m}^{3} / \mathrm{I}$ & 13,06 & 12.68 & 12.85 & 13.18 & 14.17 \\
\hline 㟟くスクレーパー & " & 16.78 & 11.41 & 14.02 & 21.65 & 24.43 \\
\hline
\end{tabular}

(b)

\begin{tabular}{c|cc|c|c}
\hline \hline & 単 & 位 & $31 / 6$ & $31 / 7$ \\
\hline ベビーコンベーヤー & $\mathrm{t} / \mathrm{I}$ & 14.0 & 15.1 \\
\hline
\end{tabular}

ケットのスビードを半分の $50 \mathrm{~m} / \mathrm{min}$ で使用している。 $550 \mathrm{~kg}$ のバケットの幅は約 $36^{\prime \prime}$ なので, これは1”当り 約 $15 \mathrm{~kg}$ になつている。

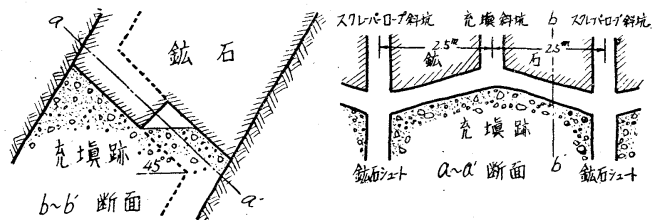

\begin{tabular}{|c|c|c|c|}
\hline \multirow{9}{*}{$\begin{array}{l}\text { 能 } \\
\text { 率 } \\
\text { 比 } \\
\text { 較 } \\
\text { 表 }\end{array}$} & & 新探 鉱 法 & 第三鉱体本均 \\
\hline & 出 鈗 量 & $930 \mathrm{t} /$ 物犲 & \\
\hline & 作 業 日 数 & 13日 (26方) & \\
\hline & 1 日当出鉱最 & $715 \mathrm{t} /$ day & \\
\hline & 1 工当出鉱量 & $133 t(701)$ & \\
\hline & 巳く岩 1 台当出鉱星 & $130 \mathrm{t} / \mathrm{厶}$ & $82.81 \mathrm{t} /$ 台 \\
\hline & $\mathrm{t}$ 当 灭薬 量 & $75 \mathrm{~g} / \mathrm{t}$ & $93 \mathrm{~g} / \mathrm{t}$ \\
\hline & スタレーパー鉱石盛 & $100 t /$ 台 & 49.6t/台 \\
\hline & スクレーパー碰か & $50 \mathrm{~m}^{2} /$ 台 & $25 \sim 30 \mathrm{~m}^{2} /$ 台 \\
\hline
\end{tabular}

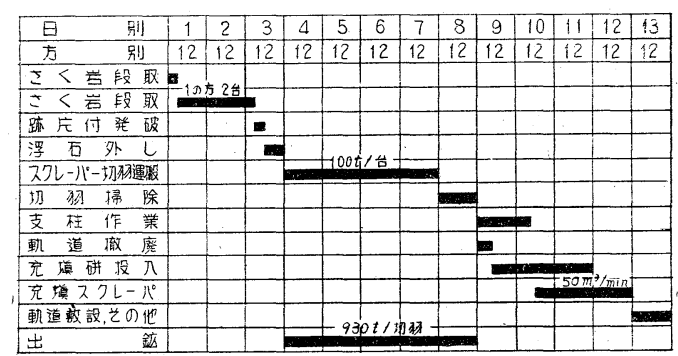

第 2 図分層傾斜無鉱柱採釷法説明図

iii スラッシャー設置点の考慮：一一スラッシャーが 大型化して来るとこれの移設が困難沈なるが，この採鉱 法では，スラッシャーは鉱体の最頂部に設置してある。 そうしてシーブでロ一プを誘導してスラッシャとバケッ トを結び，運転は信号によつている。所要人員は運転に 1 名, 切羽儿信号手 1 名計 2 名になつているが, 最近遠 方操作機が入荷するので, 切羽に和ける1名のコントロ ールにて足り，1人当り能率を上昇乙得る。

iv 起砕鉱石の細粒化：一一スクレーパーを使用する 場合，起砕鉣石を細粒化すれば，二次破砕を少なくする ととも搔込能抽上昇することが出来るし，またスク レーパーの能力を充分に発揮させるために快, 多量の鉱 石を次々儿起砕する必要が出る。採鉙切羽以和ける発破 (追切式発破) の場合，起砕鉱石を細かくするには穿孔 長と装薬長との比が間題になり少なくとる穿孔長の $1 / 2 〜$ 2/3を爆薬で満す必要がある。また穿孔配置の不船が大塊 を多くする原因になるので，穿孔を計画的配置場所深 行することにより防いでいる。このことは，1 孔当りの 装薬量を多くして第孔数を減少（最小抵抗線を大きくす る）出来るので，1切羽当りの穿孔時間を短かくするこ 
横断図 $B-B^{\prime}$

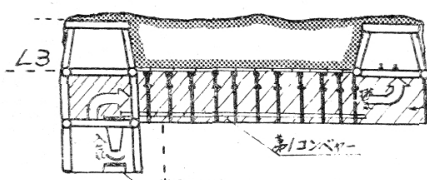

$24 \phi \sqrt{\square}$
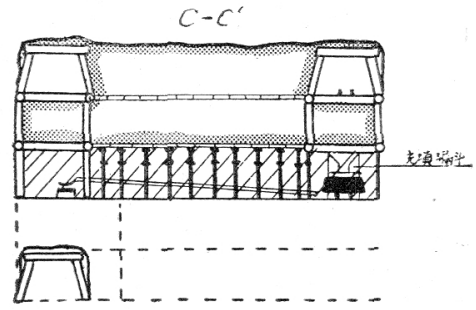

平面図 $\left(D-D^{\prime}\right.$ 断面 $)$

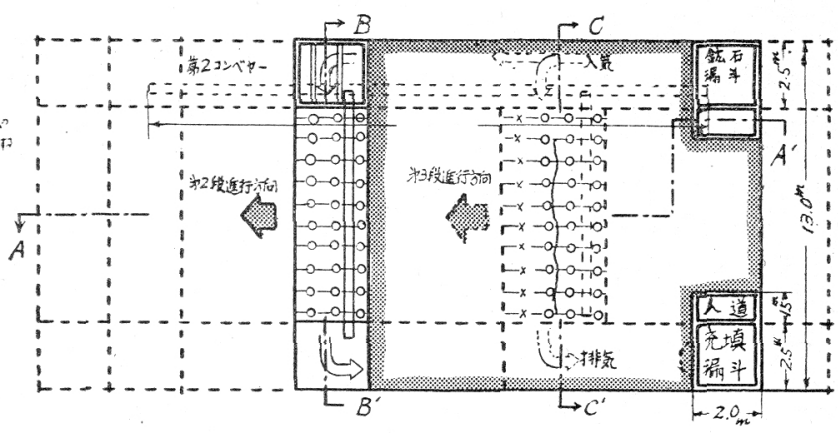

釟断図 $\left(A-A^{\prime}\right)$

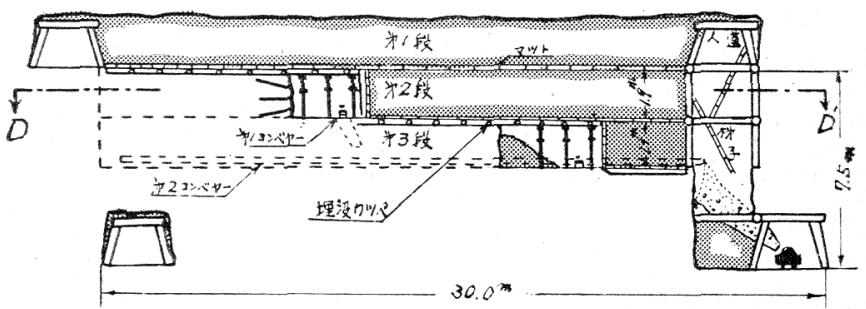

第3図 $\mathbf{A}$ 力ッ人採掘図
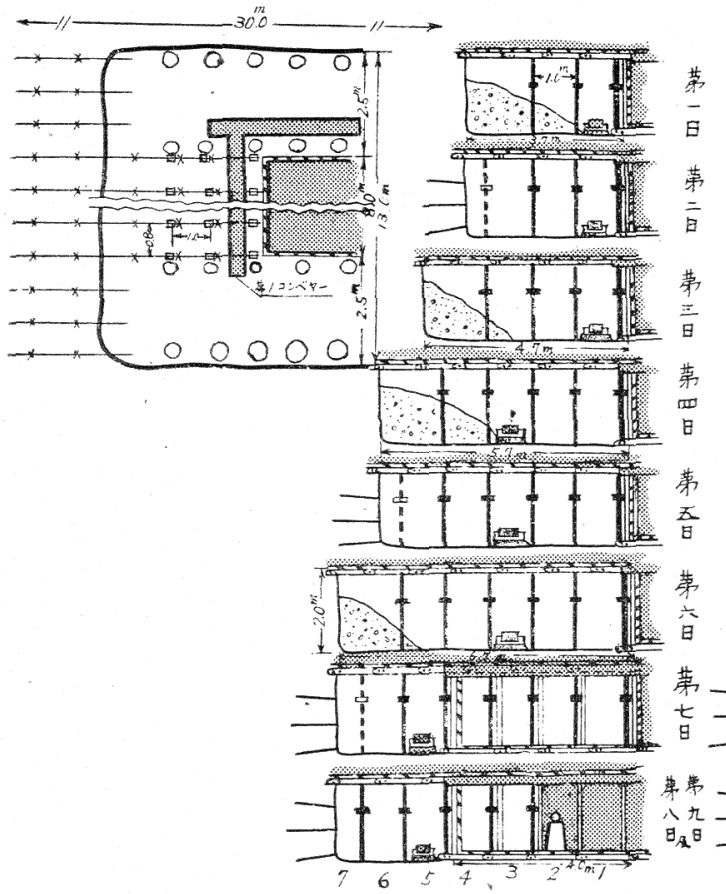

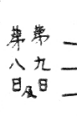
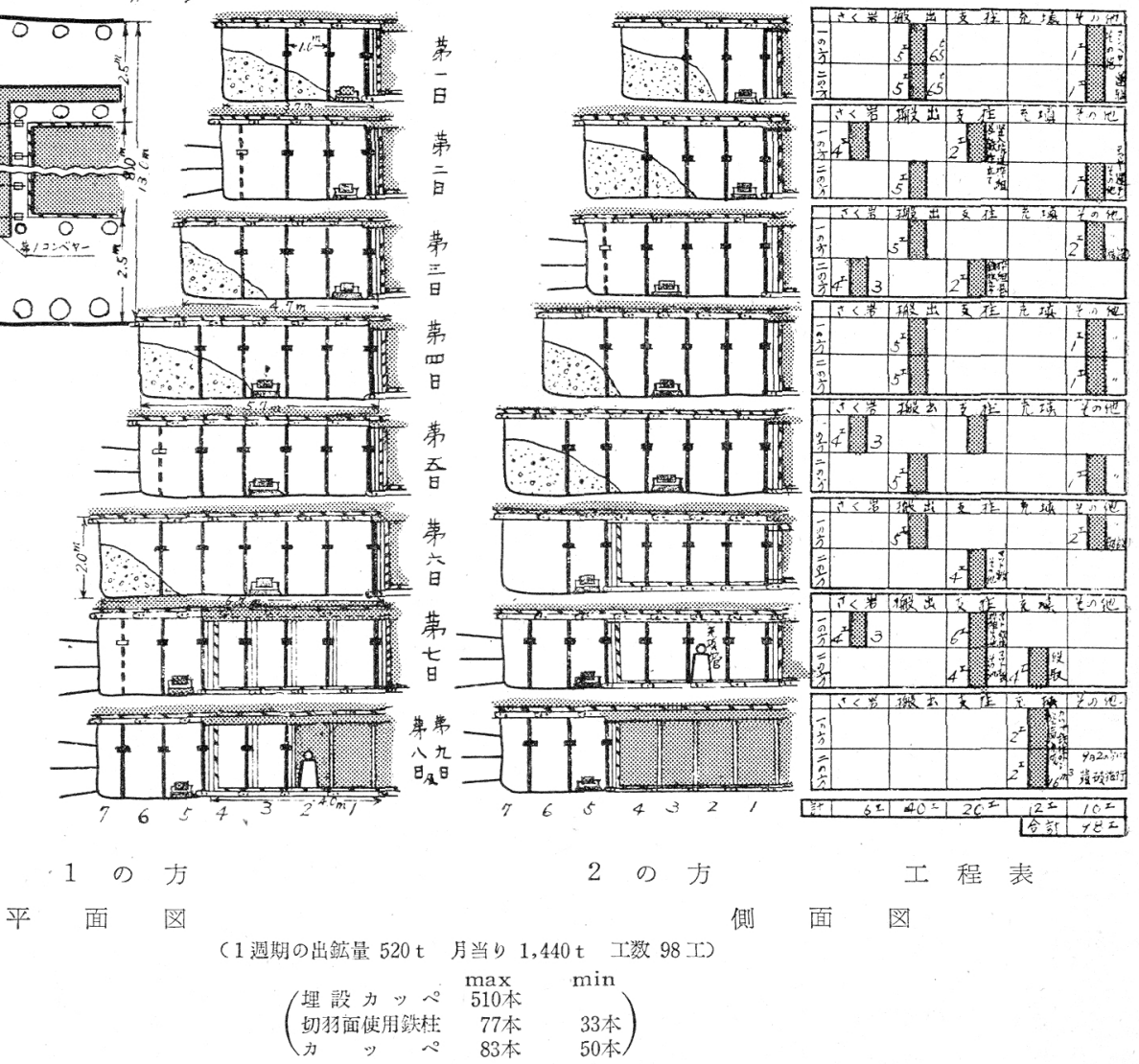

第 3 図 $\mathbf{B}$ カッペ採掘 1 週期工程袁 
とが出来るし，また最小抵抗線を $0.8 \mathrm{~m} 〜 1.0 \mathrm{~m}$ にとつ ていたるのを, 現在 $1.3 \mathrm{~m} \sim 1.4 \mathrm{~m}$ まで延ばして（もち ろん装薬量は多い）小塊を得ることにも成功している。 もち万ん発破法は M.S. D 雷管を使用して細粒化を計 つている。

\section{$2 \cdot 2$ 短壁払式カッペ採鉱法}

これは採鉙法に採鉝機械を合致させた 1 例である。こ れを実施している区域は，柵原鉣山第一鉣体の崩落箇所 で，かつては，支杜坑道採鉣法を実施していた所である が，切羽の集約化のために短壁式カッへ採鉣法を採用し た。この詳細虫昭和31年の日本鉣業協会誌3)で発表され ているので省略するが，第 3 図のように全面的に破砕さ れている区域を充填式トップスライシング法で採鉣する

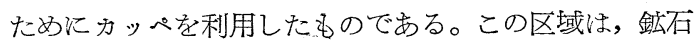
の品位も良く, かつ埋蔵量も多いので, 最近の増産体勢 に順応して，この区域の集約化が訢られたわけである が，崩落地带と云う条件化制約されて切羽長も $13 \mathrm{~m}$ に， 進行距離も $30 \mathrm{~m}$ 以内の短かいものになつている。こう いう箇所の集約化は，切羽の回転数を早くすへきで切羽 盛込を迅速化するために，ベビーコンベャーを使用して いる。この切羽は最初着手当時は, 天盤㯰接破砕鉣石 があつたために，切羽全面を一斉発破すると崩落する恐 れがあつたので, 耳欠式に追切して切羽を進め天盤を鉄 桂で受けていた。これが二層目になると，あらかじめ一 層目の時充填前にマット及びカッペを敷き込むことが出 来るので, 1 切羽全面の斑発が可能になつている。この 切羽の全面斎発が可能になつたので, 切羽運搬機械とし て, ベビーニンベャーが導大されたのである。

これは切羽面沿つてベビーコンベヤーを布設出来る ので切羽全面に人員を配置することが出来，したがつて 1方当りの出鉱量を増加することが出来た。コンぶャ゙ー 使用前は，鉱車を直接切羽に入れていたので，その時の 有効人員配置は 3 名であつたが，コン心゙ャーを使用ずる ことにより 6 人乃至 7 人を配置することが出来，乙たが つて切羽の 1 サイクルに和ける 1 日当り出鉣量は, $47 \mathrm{t}$ から $58 \mathrm{t}$ にすなわち約 $23 \%$ ビー゙ーコンベヤ一の方が増加 している。この機械の仕様は, 第 1 表に示す通りで, 軽 量かつ分解組立が容易であり，1回の移設にわずか20分 を要するのみである。

\section{3. 主要運搬坑道の運搬}

昭和26年 6 月飞完成した 4 万 $\mathrm{t}$ 起業によつて栅原鉣山 の運搬方法は一変し，いわゆる運搬の合理化が計られて いる。これに関しては, 詳細は日本鉱業会誌儿発表して いるので省略し簡単に述心ると, 坑内の主要運搬には, 普通鉣車にがわ柵原式ダンプカーを使用し, 立坑の運 搬快従来のケージ巻の代りにスキッブ巻を採用してい
る。また坑内から選鉙場までの輸送は，トロリ一電車運 搬からベルトコン心゙ャ一運般になつている。

以下これ等運般方法の改善炕よつて, 能率面, 経費面 にどのように変化したかを第 4 四相原鉣山運搬系統四に ついて述へて見る。

\section{$3 \cdot 1$ 普通鉱車による運搬と, ダンプカーによる運}

\section{搬との比較}

これは本鉣体 $6 \mathrm{~L}$ に和ける主要運搬で, 1.2 鉣体方面 の鉱石をクラッシャ一室まで運搬している方法で, 普通 鈗車 $\left(0.40 \mathrm{~m}^{3}\right)$ と, ダンプカー $\left(0.95 \mathrm{~m}^{3}\right)$ の場合を比較 すると次表のようになる。何れも 4 tトロリ一電車で運 搬している。

\begin{tabular}{|c|c|c|c|c|}
\hline 內 & 容 & 単 位 & $\begin{array}{c}0.95 \mathrm{~m} 3 \\
\text { ダンプカー運搬 }\end{array}$ & $\begin{array}{c}0.40 \mathrm{~m}^{3} \\
\text { 普通鉱車，運搬 }\end{array}$ \\
\hline \multicolumn{2}{|c|}{1 方当運搬量 } & $\mathbf{t}$ & 972 & 400 \\
\hline \multicolumn{2}{|c|}{1 方当所要人員 } & I & 6 & 5 \\
\hline 人 & 件 費 & 円/t & 5.34 & 11.30 \\
\hline 物 & 品 & !" & 0.18 & 0.22 \\
\hline 動 & 力 & " & 0.38 & 0.38 \\
\hline I & 作 & " & 3.21 & 3.04 \\
\hline & 却 費 & " & 4.66 & 6.61 \\
\hline \multicolumn{2}{|c|}{ 鉱石 $\mathrm{t}$ 当直接費 } & " & 13.77 & 21.55 \\
\hline
\end{tabular}

以上のようにダンプカーに切替えたことにより $\mathrm{t}$ 当り 7.78 円安 (36\%) になつている。また $0.4 \mathrm{~m}^{3}$ 普通鉣車 を使用した場合は漏斗拔きに11分を要し，運搬に13分を 要しているので,トロリ一電車を 2 台使用しても運搬量 をたいして堌加することが出来ない。それ故に $0.4 \mathrm{~m}^{3}$ 普 通鉱車を使用した場合， $6 \mathrm{~L}$ の運搬量は漏斗口その他の 増設をしない限り 1 方当り $400 \mathrm{t}$ 亿制限されてしまうの で，最近の増産体勢をとるためにもダンプカーに切替兄 る必要があつた訳である。

\section{$3 \cdot 2$ ケージ卷による運搬と, スキップ卷による運 搬の比較}

4 万 $\mathrm{t}$ 起業前, 坑内の鉱石は第 3 立坑 $(6 \mathrm{~L} \sim 0 \mathrm{~L})$ 旧 第 2 立坑 $(10 \mathrm{~L} \sim 0 \mathrm{~L})$ の 2 によつて, $0 \mathrm{~L}$ まで巻揚げ られていたが，旧第 5 立坑をスキップ立坑に改造するこ とにより，現在は全鉣石をこのスキップ立坑で取扱つて いる。スキップ巻運転を行つている巻揚機は $350 \mathrm{PP} 3$ 相 交流誘導電動機によるもので, 巻揚深度は $206 \mathrm{~m}$, 全速 の時が $4.7 \mathrm{~m} / \mathrm{s}$, スキップ容量は $4,000 \mathrm{~kg}$ の転覆式の

\begin{tabular}{|c|c|c|c|c|}
\hline 网 & 容 & 単 & ヶ 一 爸 & スキップ卷 \\
\hline \multicolumn{2}{|c|}{1 方当運搬量 } & $t$ & 495 & 1,026 \\
\hline \multicolumn{2}{|c|}{1 方当所要人員 } & I & 10 & 4 \\
\hline 人 & 件 費 & 円 $/ t$ & 18.00 & 3.40 \\
\hline 物 & 品 & "I & 0.50 & 0.40 \\
\hline 動 & 力 & II & 5.20 & 4.75 \\
\hline & 作 費 & "I & 2.50 & 3.40 \\
\hline \multicolumn{2}{|c|}{ 鉱石 $1 \mathrm{t}$ 当直接費 } & II & 26.20 & 11.95 \\
\hline
\end{tabular}


るのであるが; 以前は同一の巻揚機で巻揚梁度 $174 \mathrm{~m}$ (10L〜0L) をケージ巻でしていた。この両者を比較す ると次のようである。(前頁表参照)

これとよつて判るようにケージをスキップ巻変更 したことにより運船量にして約 2 倍強, 経費は环以下に することが出来た。

\section{$3 \cdot 3$ トロリー電車による運搬と, ベルトコンベヤ 一による運搬との比較}

これは，OL の運搬坑道に软いて，スキップ立坑から 選鈗場までの間の約 $570 \mathrm{~m}$ を. $0.4 \mathrm{~m}^{3}$ の普通鉱車で $4 \mathrm{t}$ トロリ一電車を使用しての運搬と (起業前の方法), 30in のベルトコンベャ一運搬とした時を比較したもので，そ の結果は次のようになる。

\begin{tabular}{|c|c|c|c|c|c|}
\hline \multicolumn{2}{|c|}{ 内 } & 容 & 単 位 & $\begin{array}{l}30 \text { in ベルトコ } \\
\text { ジ゙ャー輪邆 }\end{array}$ & $\begin{array}{l}\text { トロリー霹車渾搬 } \\
\left(0.4 \mathrm{~m}^{3}\right) \text { 鉱車使用 }\end{array}$ \\
\hline \multicolumn{3}{|c|}{ 1方当運搬鉱量 } & $t$ & 1,026 & 495 \\
\hline \multicolumn{3}{|c|}{ 1方当所要人員 } & I & 5 & 10 \\
\hline 人 & 件 & 費 & 回/t & 3.44 & 13.80 \\
\hline 物 & 品 & 費 & $\prime \prime$ & 0.54 & 0.22 \\
\hline 動 & 力 & 費 & " & 1.74 & 0.38 \\
\hline$I$ & 作 & 費 & ” & 2.79 & 3.04 \\
\hline 償 & 却 & 費 & " & 5.39 & 6.61 \\
\hline \multicolumn{3}{|c|}{ 鉱石 $1 \mathrm{t}$ 当㨁接費 } & " & 13.90 & 24.05 \\
\hline
\end{tabular}

ベルトコンぶヤーを使用した場合，輸送費が約１２程度 飞安くなつているばかりでなく, 現在のような月出鉱粗 鉝 55,000t では, ぶルトニン心゙ヤーによらなければ， 運般の円滑を期し得ない状態であり, 今後月㡾 $60,000 \mathrm{t}$ 以上の增産の場合も決して心配ないことである。

\section{4. 結言}

以上切羽運搬と, 主要運搬分分けて栅原鉣山特ける 坑内運搬の能率上昇について, 現在までとつて来た方法 を簡単に述へたが，な和前述の起砕鈗石の細粒化に対す る掘下げた彼際的研究及び崩落地带に括ける能率的な採 鉣法等については，それぞれ担当者が研究に専念してい るので，別の機会汇発表することと思う。

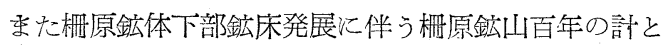
てての起業計画もすでに進められているが今回は割愛す ることにする。

\section{参 考 交 献}

1) 梅原鈗山の坑内運搬の機械化について 九州鉣山学会誌, 昭和 25 年11月

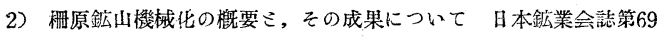
卷, 第 784 号, 昭和 28 年 10 月

3）年胹原鉱山に於ける鉄柱カッペ探鉣法について第 7 回現場担当 者会識溝演錄 昭和 31

\section{留学だより}

\section{（前略）}

正会員富田堅二

私が 6 カ月間過ごすこととなつている Colorado School of Mines Research Foundation, Inc. そ いうのは,コロラド州立である Colorado School of Mines の中にある利益を目的としない研究財団 で，鉣業に関係した委託研究を主にやっているとこ ろです。所長の下に Ore Dressing Div., Chemical Div., Special Project Div. の 3 部門があり, それぞれマネージャの下に Project Engineer と Jr. Project Eng. が㧍り，その数は各部で 100 名 に満た奴程度の規模です。建物は学校の実験工場の なかに同居しています。各部の比率から云うと，い ろいろな点で, 焙烧浸出を含めた選鉱関係が全体 の75\%を占め, 屯たその中でも時節䄲, ウラン関係 の仕事が大きな比率になつて招り，例兄ば“あるウ ラン鉱石の各種浸出法に対する適応性の試験” とい つたような場合には 500〜1,000\$の費用で， 4 〜 週間のららに極めて迅速にレポートを出していま す。この研究費はすべて実費計算で, 人件費から物 品費, 消耗品費に至るまで, 各試験研究毎に精密な 計算カードが出来て打り，中には 1 力月 $1,000 \$$ 以内で 3 力月間の試験, というように次から次へと 絶えることのない, ウラン鉣石の試験研究の中にあ つてその一部を担当しながら, 実験と交献調查に忙 しく每日を過ごして扔ります。

(中略) 大学の選鉱の授業については, 私が講義に も出ず実験ばかりなのでよくわかりませんが,過日， 低品位鉄鉱の選鉱の研究をするため米国に来られた 英国の Royal School of Mines in London の選 鉱の教授である E. Cohen 博士が当校に来られた 際，両校の選鉱の授業を比較されたのですが，それ によりますと，両校は同じテキストを使用し，同じ コースに從つているが, 英国の方が若干理論的でめ り, まだ英国では学校の実験室で実験するよりも, むしろ実技を知るために每週現地見学をしていると いらことです。これ対し当地の学生が，“英国で は富裕な学生は man-servant を雇つて, それに宿 題や実験，むるいはレポート書きをさせ，その間に 酒をのみに行つているといらことだが”と質問した のに答えて“そうした問題は自分の学校ではあまり 行つていない”といわれたそうですが，当地の学生 諸君が非常によく勉強していることはたしかです。

（編集係註）富田君驻資源技術試験所より昨年10月18日原子力関係 の研究に 6 力月の予定で留学した。问君上り本会に寄せられれ書簡 を拔書きしたるのである。 